\title{
Impact of Academic Self Efficacy and Locus of Control on Academic Achievement of high school students
}

\author{
Nehal Deora ${ }^{1}$ \\ ${ }^{1}$ Post Graduate Student, Department of Psychology, Maniben Nanavati Women's College, Mumbai. \\ E-mail-ndeora580@gmail.com
}

\begin{abstract}
Education plays an important role to promote the fullest individual selfrealization for all persons. Various factors play role in academic achievement. The purpose of the study was to examine whether there is an impact of gender, academic self-efficacy and locus of control on academic achievement. Self- report survey data were collected from $17511^{\text {th }}$ standard students between the ages 15-18. The results of 3- way ANOVA showed that a significant relationship between academic self-efficacy and academic achievement exists. However, despite supporting past studies, it was found that there was no significant relationship between (1) locus of control and academic achievement and (2) gender and academic achievement. Also the interaction effect of academic self-efficacy, locus of control and gender on academic achievement was not significant. The results of correlation indicated that academic achievement and gender as well as academic self-efficacy and locus of control were positively correlated. There was a negative correlation between academic self-efficacy and academic achievement as well as locus of control and academic achievement.
\end{abstract}

Keywords: academic self-efficacy, locus of control, academic achievement, high school.

\section{INTRODUCTION}

Education may be defined as a process designed to inculcate the knowledge, skills and attitudes necessary to enable individuals to cope effectively with their environment. Its primary purpose is to foster and promote the fullest individual self-realization for all people. Achieving this goal requires understanding of the proposition that education is a primary instrument for social and economic advancement of human welfare [1].

In the Indian education system, emphasis is given on students' scholastic achievement and success in learning is judged mainly in terms of quantitative marks obtained by the students in the year end examination. Academic achievement occupies a very important place in continuing higher education as well as in the selection and placement in any organization and institution in this ever-growing competitive world. Time spent in learning accounts for a large portion of an adolescent's life. Enjoyment in learning activities, adjustment in the school setting, and academic achievement 
represent desired attainments for both students and their families. A vast literature shows that these attainments influence children's course of life, by affecting their scholastic choices and professional aspirations, as well as their psychosocial development and well-being [2]. Among the factors contributing to these attainments are academic self-efficacy beliefs, optimal experience in learning and beliefs about personal control. Many researchers that investigated academic performance have focused on the link between Intelligence Quotient (IQ) and academic achievement [3].

Gender issues also take a centre stage in education with girls usually outperforming boys in state level examinations with statistics indicating a higher pass percentage for girls as compared to boys. Studies investigating gender differences in academic performance of students report that gender has an effect on the children's academic achievement. Authors assessed the academic achievement of the subjects among 11th class students and found that girls had a higher mean score in academic achievement compared to boys [4]. Similarly others found that girls showed better performance than boys in certain instances [5]. But some observed no significant relationship between academic achievement and sex of XI grade high school students [6].

Self-efficacy is defined in terms of individuals' perceived capabilities to attain designated types of performances and achieve specific result. Selfefficacy beliefs influence the choices individuals make and the courses of action they pursue. Efficacy beliefs help determine how much effort people will expend on an activity, how long they will persevere when confronting obstacles, and how resilient they will prove in the face of adverse situations-the higher the sense of efficacy, the greater the effort, persistence, and resilience [7]. Various studies have found liks between selfefficacy and academic achievements [8-9].

"Locus of control" (LOC) is a personality construct derived from social learning theory and seeks to explain human behaviour over a wide spectrum of situations related to learning and achievement. Rotter proposed that the potential for human behaviour is a function of generalized expectancies that one's behaviour will elicit valued reinforcement. When a reinforcement is perceived by the subject as following some action of his own but not being entirely contingent upon his action, then, in our culture, it is typically perceived as the result of luck, chance, fate, as under the control of powerful others, or as unpredictable because of the great complexity of the forces surrounding him. When an individual interprets the event in this way, we have labeled this a belief in external control. If the person perceived that the event is contingent upon his own behaviour or his own relatively permanent characteristics, we have termed this a belief in internal control [10]. A number of studies have identified significant relationships between locus of control and academic achievement [11-12].

Thus, this study seeks to investigate the impact of psychological factors such as academic self-efficacy and locus of control on the academic achievement of high school students.

\section{METHODOLOGY}

Self- report survey data was collected from students of two colleges and a coaching centre in Suburban Mumbai. The students who participated were all $11^{\text {th }}$ standard students between the ages 15-18 years. The heads of the colleges and coaching centre were contacted to explain the purpose of the study and to seek their permission for the students to participate in the study. Once they agreed the study was carried out by giving questionnaires to the consenting students. 
Demographic variables of the samples were measured using standard fact sheet items. Following scales were applied:

\section{Locus of Control}

To assess locus of control, Rotter's Locus Of Control test was used which was published by Julian Rotter in 1966. The 29-item survey consists of 23 items that receive either 1 point or zero points for the answer and 6 filler items that receive no score. The 23 items are then summed; a higher total score indicates a locus of control that is more external and a lower total score indicates a locus of control that is more internal [10]. The reliability of Rotter's Internal-External Locus of Control Scale has been confirmed by several different studies [13-14].

\section{Academic Self-Efficacy}

Morgan Jinks Student Efficacy Scale (MJSES) was created to assess student's efficacy beliefs about his or her school performance. The initial version of MJSES consisted of 53 items, plus four items of student's self-report grades. This early version of the scale was consisted of four subscales: talent, effort, task difficulty, and context [15]. The new and refined scale has 30 items with an overall reliability of 0.82 and this was used in our study.

For the purpose of this study, academic achievement was taken as the total marks obtained by the student in tenth standard State Board Examination which is a standardized examination. The collected data was interpreted with the computerised software and analysed.

\section{RESULTS}

The sample consisted of 175 students studying in 11 th standard of which $51.43 \%$ were males and $48.57 \%$ were females. The participants' ages ranged from 15 to 18 years of age. The mean values for participants' academic selfefficacy scores were $59.22 \pm 8.145$, locus of control scores was $9.90( \pm 9)$, for academic achievement scores were $375.84 \pm 38.31$. The three-way ANOVA or factorial ANOVA was used to determine if there is an interaction effect between the three independent variables used in the study on the continuous dependent variable. Table 1 shows that effects of academic self-efficacy on academic achievement was significant but there was no significant effect of locus of control and gender on academic achievement. The interaction effects between academic self -efficacy, locus of control and gender on academic achievement were not significant.

Pearson's Correlation results indicated that academic achievement and gender were positively correlated whereas there was a negative correlation between academic self-efficacy and academic achievement as well as locus of control and academic achievement. Of these only correlation between academic achievement and self-efficacy was statistically significant [Table 2].

\section{DISCUSSION}

The purpose of our study was to examine whether there is an impact of academic self-efficacy and locus of control on academic achievement. There was also an attempt to observe if there was a difference in the academic achievement of 
Table 1

\begin{tabular}{|cccccc|}
\hline Source & $\begin{array}{c}\text { Sum of } \\
\text { Squares }\end{array}$ & df & $\begin{array}{c}\text { Mean } \\
\text { Square }\end{array}$ & F & $\begin{array}{c}\mathbf{p} \\
\text { value }\end{array}$ \\
\hline Academic self-efficacy & 9149.961 & 1 & 9149.961 & 6.381 & .012 \\
\hline Locus of control & 1001.899 & 1 & 1001.899 & .699 & .404 \\
\hline Gender & 1449.268 & 1 & 1449.268 & 1.011 & .316 \\
\hline $\begin{array}{c}\text { Academic self-efficacy and } \\
\text { Locus of control }\end{array}$ & 1321.085 & 1 & 1321.085 & .921 & .339 \\
\hline $\begin{array}{c}\text { Academic self-efficacy } \\
\text { and Gender }\end{array}$ & 9.575 & 1 & 9.575 & .007 & .935 \\
\hline Locus of control and Gender & 115.095 & 1 & 115.095 & .080 & .777 \\
\hline Academic self-efficacy and LOC & 576.668 & 1 & 576.668 & .402 & .527 \\
\hline
\end{tabular}

Table 2 - Correlation between the factors

\begin{tabular}{|cccc|}
\hline $\mathbf{N}=175$ & Academic self-efficacy & Locus of Control & Gender \\
\hline Academic Achievement & $r=-0.209$ & $r=-0.116$ & $r=0.050$ \\
& $p=0.003$ & $p=0.063$ & $p=0.256$ \\
\hline
\end{tabular}

boys and girls with respect to academic self-efficacy and locus of control. The study is important as it would provide an insight into how personality or motivational variables affect the academic achievement of Indian students. The results of our study that students with high academic self-efficacy have higher academic achievement is in line with past studies that demonstrated that young people who believe in their capabilities to exercise control over their educational performance, achieve higher results academically than counterparts who have less efficacious beliefs in their academic pursuits [16-18].

Our study did not find statistically significant relation between locus of control and academic achievement. This was not in line with previous studies that show that a significant relationship exists between an internal locus of control orientation and academic success $[11-12,19]$. These studies also show that an external locus of control is negatively related to school achievement. But our finding corroborates the findings of some who did not find any significant correlation between academic achievement and locus of control [20]. Researchers have reported that the relationship between locus of control and achievement could also be spurious; shared variance with some third variable such as mental age, socioeconomic status, or IQ might account for the relationship [21-22]. The study uses a convenience sample based on students from Suburban Mumbai. This is a threat to the external validity of the study since the sample tested may not have been representative of the population at large (high school students). Academic achievement in the study was taken as the total marks obtained by the students in 10th standard Board Examination. So this can also be the reason for our results.

Our study did not find any significant relationship of gender on academic achievement which is in contrast to studies that found a significant relationship between gender and academic achievement [4-5]. The result corroborates the findings of Farquhan who observed no significant relationship between academic achievement and sex of XI grade high school students [6]. Kaur and Gill also did not find 
any significant relationship between gender and academic achievement [23]. Our study also did not find significant relationship between academic self-efficacy and locus of control. In this study, individual personality variables were examined to see if they have an impact on the academic achievement of students. In Indian context, rather than individual variables, parental and societal factors could be more adept and predictive of achievement in educational pursuits. The environment characteristics of learners can have an important role in their academic success. The school personnel, members of the families and communities can be crucial in providing help and support to students in order to improve the quality of their academic performance.

Our study had limitations like the constricted nature of the sample size as it was a convenience sample which possibly could not be representative of the population from which it was drawn. In this study only individual personality and motivational factors were considered. Future research in the area could examine broader factors related to parental support, societal expectations, career aspirations, socioeconomic status, parent's education level as well as other individual factors like meta-cognition, self-concept, anxiety levels, academic procrastination and so forth.

\section{REFERENCES}

1. Verma V, Saxena PC, Mishra U. Socio- Economic status Index. Agra.1990.

2. Caprara GV, Barbaranelli C, Steca P, Malone PS. Teachers' self-efficacy beliefs as determinants of job satisfaction and students' academic achievement: A study at the school level. J School Psychol 2006;44(6):473-90.

3. Snow RE, Yallow E. Education and intelligence. In R.J. Sternberg (Ed.) Handbook of human intelligence. New York: Cambridge University Press ; 1982. pp. 493-585

4. Vijayalaxmi $\mathrm{N}$, Natesan $\mathrm{H}$. Factors influencing academic achievement. Research Highlights, $1992 ; 2: 62-6$.

5. Chambers EA, Schreiber JB. Girls' academic achievement: varying associations of extracurricular activities. Gender Educ 2004;16(3):327-46.

6. Farquhan A. A comparative study of Motivational Factors underlying Achievement of Eleventh Grade High school studies. Columbia University Team Library ; 1963.

7. Bandura A. Self-efficacy: The exercise of control. New York: Freeman ; 1997. pp. 231-251.

8. Pajares F. Self-efficacy beliefs in achievement settings. Rev Educn Res 1996;66:543-78.

9. Pintrich PR, DeGroot E. Motivational and self-regulated learning components of classroom academic performance. J Educ Psychol 1990;82:33-40.

10. Rotter JB. Generalized expectancies for internal versus external control of reinforcement. Psychological monographs: General and applied ; 1966.

11. Weiner B. A theory of motivation for some classroom experiences. J Educ Psychol 1979; 71:3-25.

12. Millar B, Irving $\mathrm{E}$. Academic locus of control in British undergraduate students, $\mathrm{Br} J$ Educ Psychol 1995;65:331-40.

13. Zerega WD, Tseng MS, Greever KB. Stability and concurrent validity of the Rotter internalexternal locus of control scale. Educ Psychol Measurement 1976;36(2):473-5.

14. Lange RV, Tiggemann M. Dimensionality and reliability of the Rotter I-E locus of control scale. J Personal Assess 1981;45(4):398-406.

15. Jinks J, Morgan V. Children's perceived academic self-efficacy: An inventory scale. The Clearing House 1999;72(4):224-30.

16. Zimmerman BJ, Bandura A, Martinez-Pons M. Self-motivation for academic attainment: The role of self-efficacy beliefs and personal goal setting. Am Educ Res J 1992;29:663-76.

17. Downs PA. A comparison of student and parent perceptions of academic efficacy, abilities and support: Their impact on Native American high school students academic achievement. 2005. Unpublished doctoral dissertation. Brigham Young University, Provo, UT. 
18. Azar FS. Self-Efficacy, Achievement Motivation and Academic Procrastination as Predictors of Academic Achievement in Pre-College Students. Proceeding of the Global Summit on Education ; 2013.

19. Findley MJ, Cooper HM. Locus of control and academic achievement: A literature review. J Personal Soc Psychol 1983;44:419-27.

20. Gadzella BM, Ginther DW, Williamson JD. Study skills, learning processes and academic achievement. Psychol Rep 1985;61(1):167-72.

21. Frieze I, Weiner B. Cue utilization and attributional judgments for success and failure. J Personal Soc Psychol 1971;39:591-606.

22. Friend R, Neale J. Children's perceptions of success and failure: An attributional analysis of the effects of race and social class. Dev Psychol 1972;7:124-8.

23. Kaur R, Gil TK. Sex difference in academic achievement in different subjects of rural and urban students. Indian Psychological Review 1993;40(12):20-4.

Acknowledgements - Nil

Conflict of Interest - Nil

Funding - Nil. 